\title{
Impact Analysis of NPP Construction on National Economy using EMPOWER Model
}

\author{
Suparman ${ }^{\star 1}$, Nuryanti ${ }^{1}$, Elok S Amitayani ${ }^{1}$ \\ ${ }^{1}$ Center for Nuclear Energy System, National Nuclear Energy Agency (BATAN) Jl. Kuningan Barat, Mampang Prapatan, South \\ Jakarta, DKI Jakarta, Indonesia
}

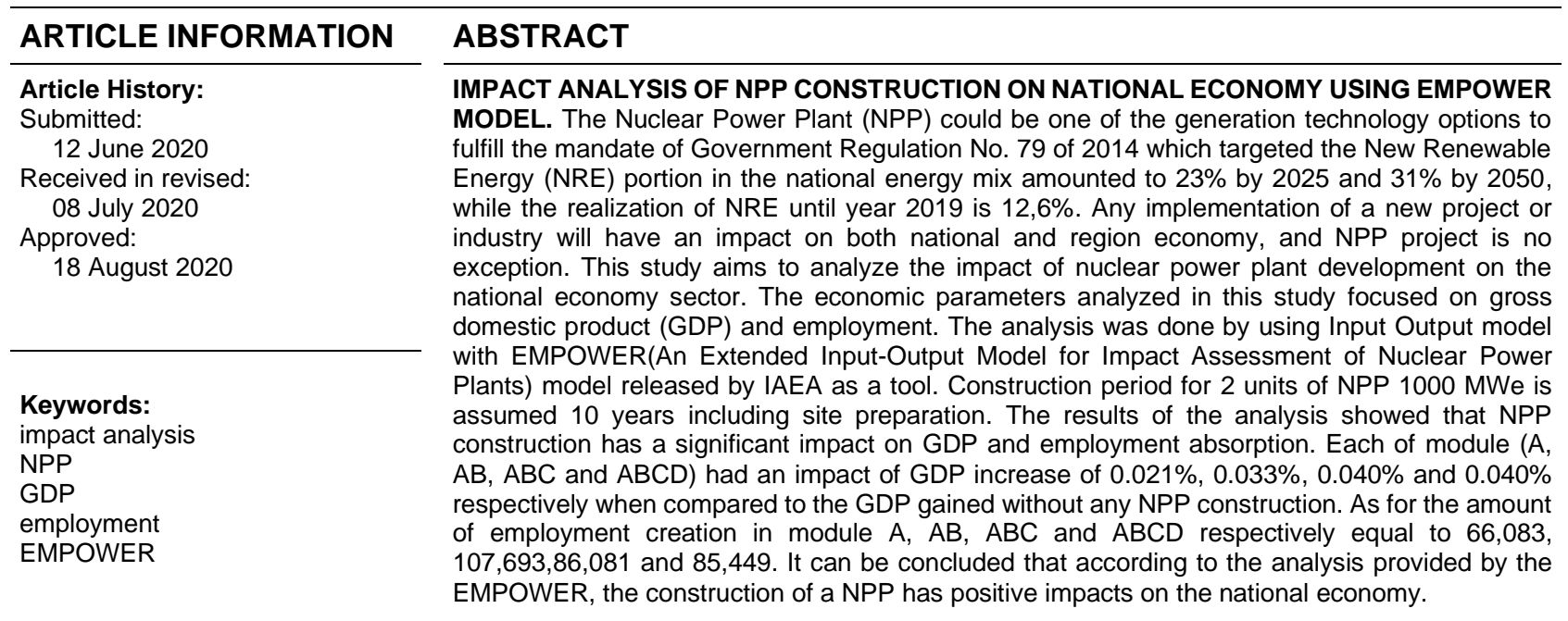

\begin{abstract}
ABSTRAK
ANALISIS DAMPAK PEMBANGUNAN PLTN PADA EKONOMI NASIONAL DENGAN MODEL EMPOWER. Pembangkit Listrik Tenaga Nuklir (PLTN) dapat menjadi salah satu opsi teknologi pembangkitan untuk memenuhi amanat PP No 79 tahun 2014 yang mengamanatkan target porsi Energi Baru Terbarukan (EBT) dalam bauran energi nasional sebesar 23\% pada tahun 2025 dan $31 \%$ pada tahun 2050, capaian target sampai tahun 2019 baru 12,6\%. Setiap implementasi proyek atau industri baru akan memberikan dampak terhadap perekonomian wilayah, tak terkecuali proyek PLTN. Penelitian ini bertujuan untuk menganalisis dampak dari pembangunan PLTN terhadap perekonomian nasional. Parameter perekonomian yang dianalisis focus pada Produk Domestik Bruto (PDB) dan penyerapan tenaga kerja. Analisis dilakukan dengan Metode Input Output dengan bantuan model EMPOWER (An Extended Input-Output Model for Impact Assessment of Nuclear Power Plants) yang dirilis oleh IAEA. Masa konstruksi untuk 2 unit PLTN berdaya $1000 \mathrm{MWe}$ diasumsikan selama 10 tahun termasuk untuk penyiapan tapak. Hasil analisis menunjukkan bahwa pembangunan PLTN memberikan dampak yang signifikan terhadap PDB dan penyerapan tenaga kerja. Untuk modul $A, A B, A B C$ dan $A B C D$ masing-masing memberikan dampak peningkatan PDB sebesar $0,021 \%, 0,033 \%, 0,040 \%$ dan $0,040 \%$ jika dibandingkan dengan perolehan PDB tanpa adanya pembangunan PLTN. Adapun jumlah tenaga kerja yang terserap pada modul $A, A B, A B C$ dan $A B C D$ masing-masing sebesar $66.083,107.693,86.081$ dan 85.449. Dapat disimpulkan bahwa berdasarkan analisis dengan model EMPOWER, pembangunan PLTN mempunyai dampak positif pada perekonomian nasional Kata kunci: Analisis dampak, PLTN, PDB, tenaga kerja, EMPOWER
\end{abstract}

(c) 2020 Jurnal Pengembangan Energi Nuklir. All rights reserved

\section{INTRODUCTION}

Propelled by economic development and population growth, the electricity demand is expected to increase fast in Indonesia. Based on the National Energy Planning, the target of installed capacity in 2025 is $135 \mathrm{GW}$ and 443 GW in 2050, meanwhile until 2019 installed capacity only 69.1 GW [1]. Achieving this goal requires large increases in electricity supply and the Indonesian power sector needs to develop accordingly. The Nuclear Power Plant (NPP) could be one of the electricity generation technology options to fulfill the mandate of Government Regulation No. 79 of 2014 which targeted the New Renewable Energy (NRE) portion in the national energy mix amounted to $23 \%$ by 2025 and $31 \%$ by 2050 [2]. 
Investment has an important role for the process of economic growth, increased output, job creation and additional community income that can reduce poverty. Investment can increase production capacity through capital accumulation so that it can encourage increased output and drive sustainable economic growth [3]. Investment not only affects the formation of national output but can also affect the reduction in unemployment. Investment will produce technical advances that support the achievement of the economy on a larger scale so that investment can affect the economic prosperity of a nation because investment will meet everything needed by a population that is always increasing [4]. The role of infrastructure as a locomotive of national and regional development is urgently needed to drive economic growth. From a macroeconomic perspective, the availability of infrastructure services affects the marginal productivity of private capital, whereas in the context of the micro economy, the availability of infrastructure services affects the reduction of production costs [5].

The construction of nuclear power plants is as a form of investment. At the construction stage will require goods and services both in the national and regional scope. The need for goods and services during the construction of nuclear power plants will be able to drive other economic sectors as well as job creation. As an illustration, the results of a survey of national industry participation in the construction of nuclear power plants will be around 25\% [6]. This means the construction or investment costs of the nuclear power plant are $25 \%$ from the whole investment will be part of the domestic portion.

For this reason, it is necessary to analyse the economic impact of the development of the nuclear power plant, particularly the impact on the national economy. As a first step, it is important to know in general the state of the economy which sector is dominant in the demand for output, the structure of output and the structure of value added, both according to the business sector and its components as well as the structure of the final demand. In addition, it also needs to be explored sectors that have a high degree of dispersal and sensitivity (backward and forward linkages effect), as well as an analysis of labour needs.

An input-output model was applied for the analysis of the economic impacts of NPP development. This input-output model was first developed by Professor Wassily Leontief in the late 1930s. For this development, he won the Nobel Prize for economics in 1973 [7]. In its development, methods derived from an $\mathrm{I}-\mathrm{O}$ table are increasingly being used as practical and quantitative economic analysis and planning tools [8][9][10][11].

The IAEA has outlined how data,technical and economic parameters from nuclear power plants can be used in analyzing the impact of nuclear power plant projects on the economy in Korea [12]. The economic parameters analyzed in this study are gross domestic product (GDP) and employment. Basically, GDP is the amount of goods and services produced by all economic units in a country in a certain period of time (generally annually or quarterly) [13]. The model released by the International Atomic Energy Agency (IAEA) in October 2014 (revised in December 2015), the An Extended Input-Output Model for Impact Assessment of Nuclear Power Plants (EMPOWER) will be used in this impact analysis [14][15][16]. This study aims to analyze the impact of nuclear power plant development on the national economy sector, and focuses only on GDP and job creation impact of nuclear power plant construction activities, not including the impact of nuclear power plant operations

The study focused on GDP and job creation impact of nuclear power plant construction activities, not including the impacts of nuclear power plant operations.

\section{EMPOWER MODEL}

The analytical method used in this study is the Input-Output method and a module called EMPOWER developed by IAEA. Using this tool can be simulated the effect of NPP constructionon macro economic. The effect on increasing demand will cause on the production of commodity and as well as the production of other commodities (multiplier effects) [16].

The EMPOWER model is a form of an advanced version of a simple static Input- 


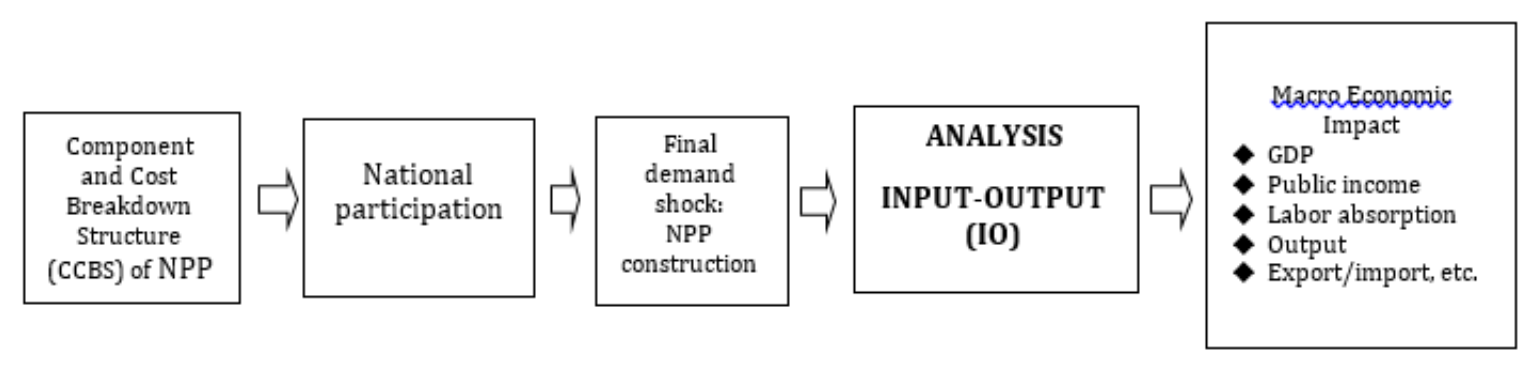

Figure 1. Logical Framework

Output model, where the framework model of the EMPOWER is designed for impact analysis involving 4 scenarios or modulesof calculating impacts, namely:

1. ModuleA is the indirect effects scenario. In this scenario, the calculation of the impact of an industry or new project includes direct effects and indirect effects.

2. Module $\mathrm{AB}$ is the indirect andinduced effects scenario. In this scenario, the calculation of impacts includes not only direct effects and indirect effects, but also involves induced effects.

3. ModuleABC is the indirect andinduced effects \& labour market response scenario. This scenario is basically an impact calculation with the $\mathrm{AB}$ scenario added by the response of the labour market.

4. The $A B C D$ module is the indirect and induced effects \& labour market response and feedback scenario from financing of investment. This scenario is basically an impact calculation with the $\mathrm{ABC}$ scenario coupled with feedback from investment financing.

The sequence of scenarios for the impact calculation of $\mathrm{A}-\mathrm{ABCD}$ illustrates the additional structure of the impact, where each version of the scenario from $\mathrm{AB}$ to $\mathrm{ABCD}$ each combines all versions of the scenarios below plus one additional feature.

The basic IO equation for symmetric IO tables is expressed in Equation (1) [15][16][17].

$X=A^{d} X+c p+f^{*}+f^{n e w}$

Where:

$\mathrm{X} \quad$ :gross output column vector

Ad : input coefficient matrix cp : column vector of private consumption which is assumed to be an endogenous variable

$\mathrm{f} * \quad$ : another final demand column vector which is an exogenous variable

$\mathrm{f}^{\text {new }} \quad$ : vector column demand of new industrial or project activities

\section{METHOD}

The impact of the NPP construction on the national economy was analyzed according to the logical framework presented in Figure 1. The analysis of the component and cost breakdown structures, and the cost components of the nuclear plant construction indicate the final demand for inputs that will be acquired. This value will be used as a shock in an input-output analysis to calculate the macroeconomic impacts.

The first step in the study is the analysis of the main components of the NPP and the preparation of the Input-Output Table (IOT). The component analysis provides data on demand for products of several economic sectors that serve as inputs to the input-output analysis. The results of the input-output analysis include indicators that show the impacts of the power plant construction on the economy. The EMPOWER developed by the IAEA was used for the impact assessment.

\subsection{Input Output Table}

The IOT used in this study is a $35 \times 35$ industry-by-industry table taken from the World Input-Output Database [18]. It is adjusted by using the Indonesian IOT for the year 2010. The reason for not using the Indonesian IOT is that it is not assembled industry by industry [19]. 
The top five industries (manufacturing, agriculture, forestry and fishing, wholesale and retail trade and repair of motor vehicles, mining and quarrying, and construction)with the largest sectoral value added produced about $70 \%$ of the total gross value added at basic prices in that year [20].

\subsection{NPP Component Costs}

The main components of the construction costs comprised of direct cost (equipment, building and civil engineering cost, contingencies and possibly the initial core fuel) that are directly related to the work on the buildings and plant systems; indirect costs (owner's cost such as the costs of land acquisition, power and water supply, and consulting if needed as well as interest during construction).

Table 1. Summary of Construction Cost [21]

\begin{tabular}{ccc}
\hline No. & Item & Cost (million USD) \\
\hline 1 & M \& E system cost & 6,107 \\
2 & Building cost & 571 \\
3 & Civil cost & 987 \\
4 & Initial core fuel cost & 553 \\
5 & Contingency & 1,644 \\
6 & Owner's cost & 1,385 \\
\hline & Total & 11,247
\end{tabular}

Table 1 shows the investment costs of $2 \times 1000$ MW NPPs obtained from the feasibility study of the non-site aspects, where Interest During Construction and Tax not included, and Figure 2 states investment disbursement during the construction period. Construction period for 2 units of NPP 1000 MWe is assumed 10 years including site preparation starting from year 2025.

Based on construction costs then the cost per year is outlined based on the nuclear power plant construction schedule (disbursement). It is seen that the equipment component accounts for more than $50 \%$ of the total construction costs and the peak of financing occurs in 2030 to 2032 .

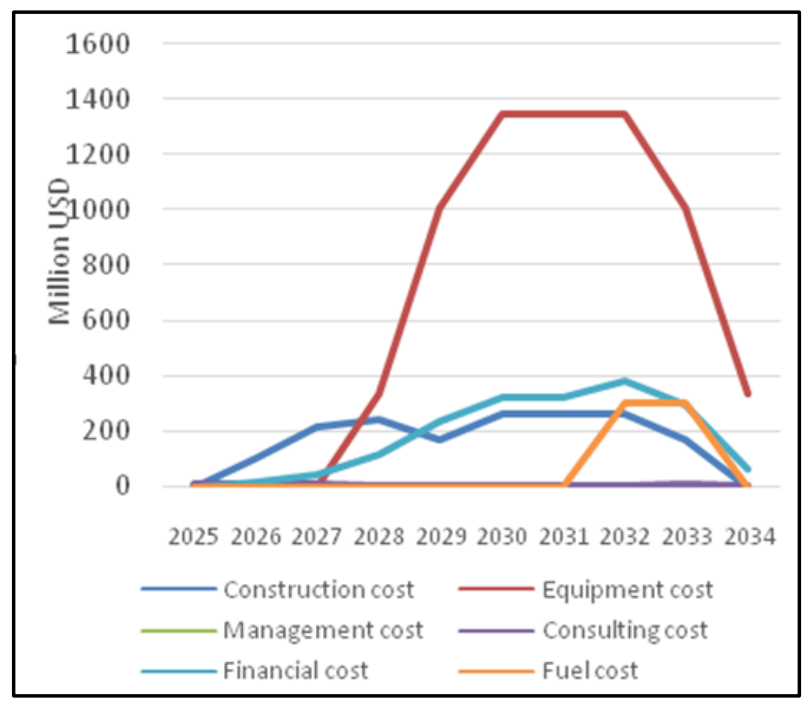

Figure 2.Investment disbursement for each cost component

\subsection{National Participation}

The capabilities of domestic industries to produce the NPP components can give information of economic effect. However, only Balance of Plant (BOP) components, few Nuclear Island component and Turbine Generator can be produced by domestic industries. This information estimates the domestic cost, and also all service activities in connection with NPP construction that can be provided by national industry that could contribute domestic cost.

The level of national participation can be calculated by Equation (2) [22].

$$
P=\sum\left[P_{i} x \frac{B_{i}}{B}\right]
$$

Where:

$\mathrm{P}$ : Total possible national participation ratio $(\%)$

Pi : Possible national participation ratios in each area (\%)

$\mathrm{Bi}$ : Estimated detailed cost of each area

$\mathrm{B}$ : Estimated total cost of NPP construction

Based on the results of previous studies and data on the ability of the current national industry, it has been estimated the level of national industry participation in the construction of nuclear power plants. The share of components that can be produced locally is around 25\% (based on total 
investment costs) for the first NPP [23][24][25][26][27]

\subsection{Domestic Cost Mapping in Economy Sector according Input-Output Table}

After identifying which components can be produced by domestic industry then price can be predicted. Match the component to the Input-Output Table to identify which industry sector produces this component. Then, the calculation of price of component for each input-output table economic sector can be done. Finally we can get the nominal of industry sector.

The impact analysis should start from the Component and Cost Break-Down Structure analysis. This shows that there is a limited capacity of the domestic industries to supply component in the building of the NPP. Only around $25 \%$ of the total construction costs are spent within the country. Therefore, impact analysis should show how the domestic industries be influenced by the project.

Based on industrial survey, areas and participation rate are as follows:

- Civil Works, Building and Structure (70\%)

- Low Pressure Heater (10\%)

- Piping and Valves (5\%)

- Tanks (10\%)

- Electric Power Systems (5\%)

- Installation and Test Operation (40\%)

The areas where we can participate are adjusted to the sectors in the input output table. As an example: civil works, building, structure, installation and test operation is construction sector in IOT.Then share of domestic or local contribution become as shown in Table 2 .

Table 2. Share of domestic

\begin{tabular}{lrrr}
\hline & Cost & $\begin{array}{c}\text { Domestic } \\
\text { portion }\end{array}$ & $\begin{array}{r}\text { Share of } \\
\text { domestic }\end{array}$ \\
\hline Construction & 1714 & 1199.8 & 0.70 \\
Equipment & 6722 & 1008.3 & 0.15 \\
Management & 20 & 0 & 0 \\
Consulting & 69 & 0 & 0 \\
Financial & 1812 & 634.2 & 0.35 \\
Fuel & 609 & 0 & 0 \\
\hline \multicolumn{1}{c}{ Total } & 10,946 & 2,842 & 0.26
\end{tabular}

\section{RESULTS AND DISCUSSION}

Based on the features of the national economy and the assumptions presented in the section 3, the impact analysis shows how the domestic industries are influenced by the NPP construction project. Charts in this section present the impacts in percentage terms relative to the Baseline case in which no investment is made to build a NPP. As the scope of the impact calculations is broadened to include more impact and feedback mechanisms (i.e. moving from Module A to $A B C D$ ), results always include impacts of the previous steps.

\subsection{Results by impact mechanisms}

According to the assessments provided by the EMPOWER, the construction of a NPP has positive impacts on the national economy. The impacts are proportional with the amount of money spent for construction activities in a given year and the contribution of the domestic industries in that year. Direct and indirect impacts measured according to the seven macroeconomic indicators: GDP, production, Export, Employment, Disposal Income, Public Saving and Import (calculated by Module A) are presented in Figure 3. Even Impact on Public Net Saving is negative but give positive impact to national economy by reducing deficit budget. Extending the scope of the macroeconomic impact assessment to include the repercussions of direct and indirect impacts of increasing personal incomes through employment creation by the construction work - which, in turn, leads to higher household expenditures on goods and services purchased from different sectors - provides the induced impacts of the nuclear plant construction. Results for the induced effects (calculated by Module AB) are presented in Figure 4. 


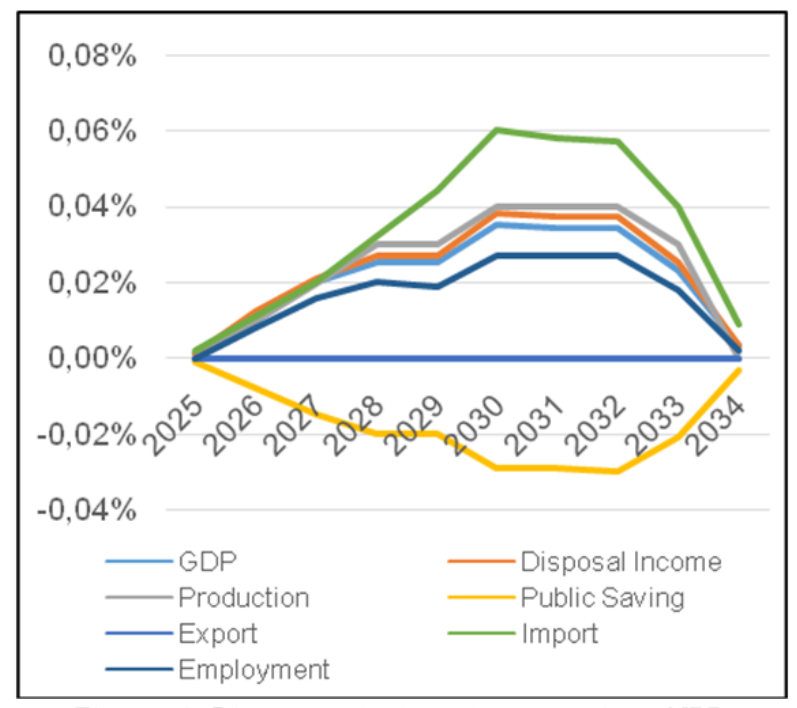

Figure. 3. Direct and indirect impacts of the NPP construction (change relative to the Baseline case).

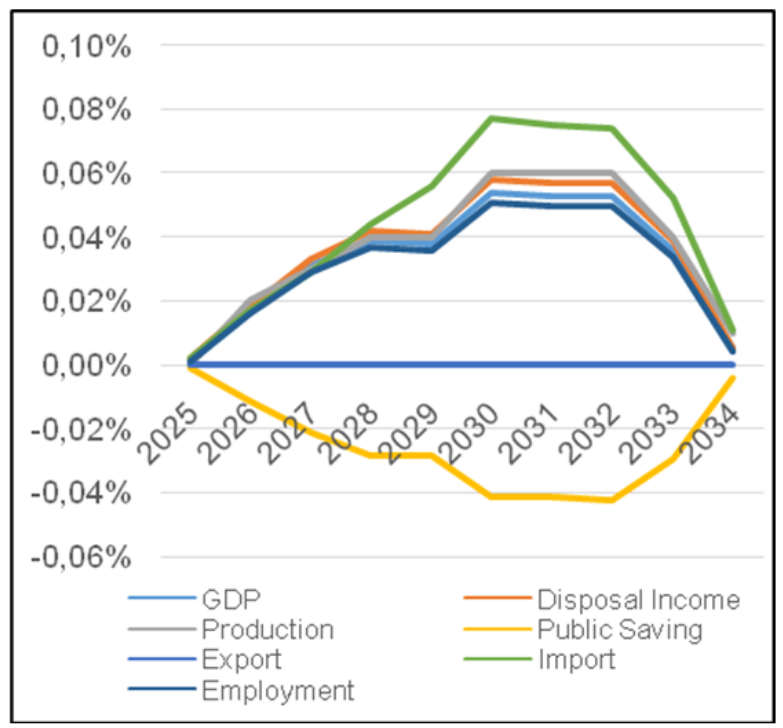

Figure. 4. Induced impacts of the NPP construction (change relative to the Baseline case).

The NPP construction generates changes in the Indonesian labour market with feedback on the rest of the economy. The representation of the labour market in the EMPOWER imitates a wage bargaining or a wage curve model. Increasing industry wage rates affect employment. Labour market and the resulting wage effects can also bring about changes in output prices. Results of the combined calculations of the labour market and the price effects (calculated by Module ABC) are presented in Figure 5.

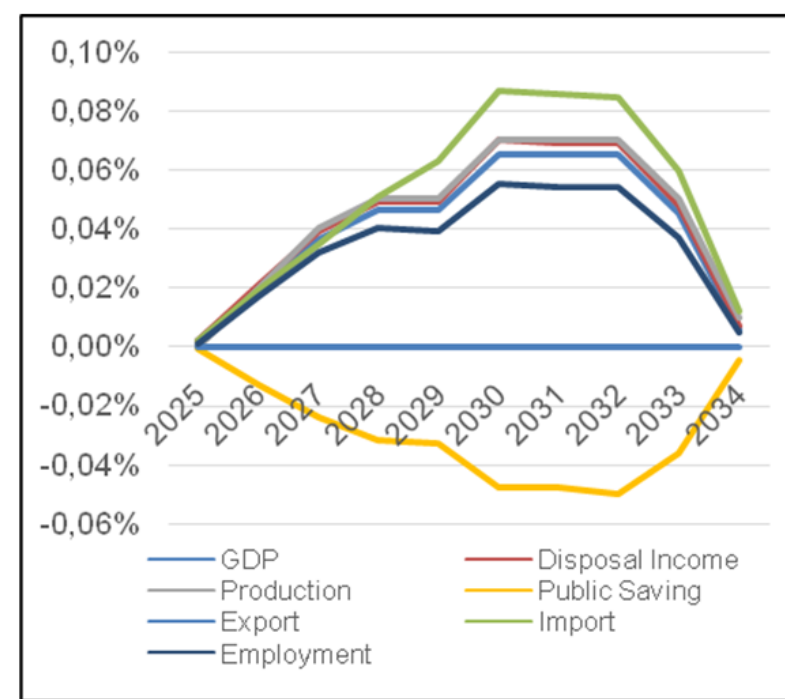

Figure. 5. Labour market impacts of the NPP construction (change relative to the Baseline case)

The ex-ante financing of the nuclear plant construction can be realized by increasing the households' tax rate and/or by decreasing public transfers to households in a revenue-neutral manner during the construction phase. Accordingly, taxes increase and/or transfers decrease to cover a predefined share of the construction costs by the government. The new tax rates and/or the new transfers affect the disposable household income that triggers changes across the whole national economy. The resulting impacts (calculated by Module $\mathrm{ABCD}$ ) are presented in Figure 6.

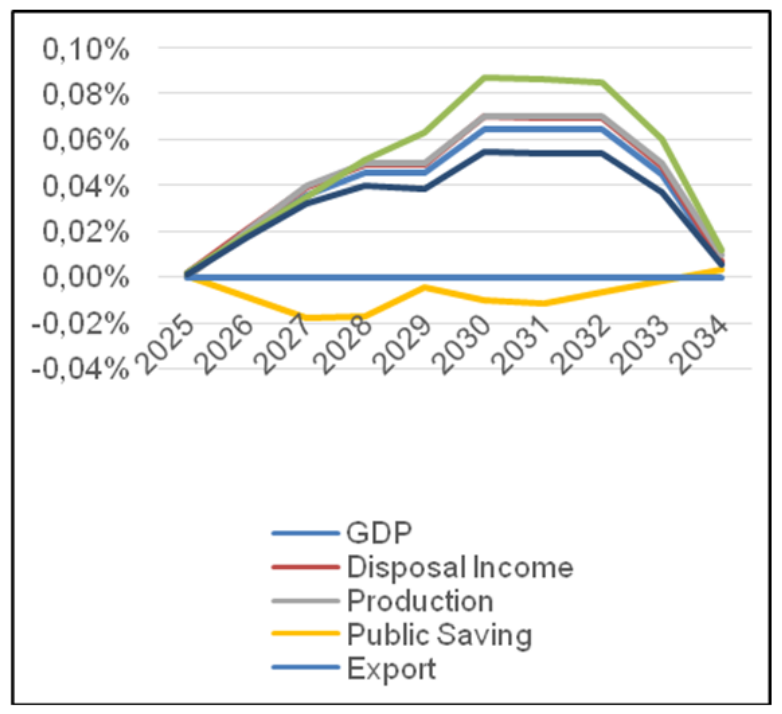

Figure. 6. Impacts of ex ante financing of the NPP construction (change relative to the Baseline case). 
Relative to others indicators, impacts on imports show the largest effects of the NPP construction. As noted above, the reason is that almost $75 \%$ of the investment costs are spent on importing equipment for the plant. Similarly to some other indicators, the impacts on imports are very similar in the case when the labour market feedback is considered (calculated by Module $\mathrm{ABC}$ ) to the case when consequences of financing are also included (calculated by Module ABCD).

\subsection{Impact on GDP}

The construction of NPP is projected to have positive impacts on the Indonesian economy. Results of the EMPOWER show that the total GDP in 2032 amounts to 35,540,665,551 million Rupiah in the Baseline case and it increases by about $0.016 \%$ to 35,546,257,543 million Rupiah when the NPPs is built and its direct and indirect effects are considered (Module A). The increase in GDP would be $0.021 \%$ if induced effects are also considered (Module AB), and $0.023 \%$ if labour market responses are also accounted for (Module $\mathrm{ABC}$ ). The impacts on GDP are very similar to the labour market results (Module $\mathrm{ABC}$ ) when effects of financing are also included (Module ABCD). The changes induced by the NPP construction in GDP under the four main impact mechanisms are presented in Figure 7.

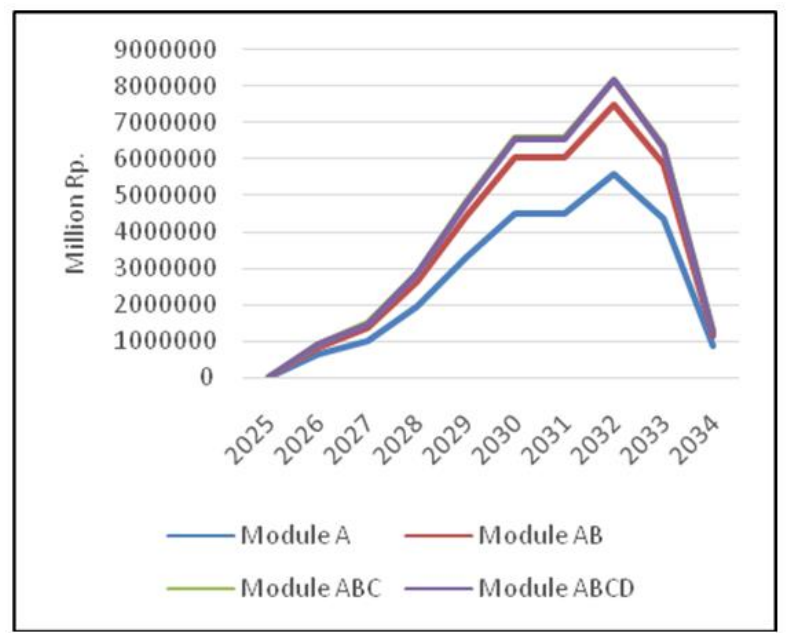

Figure. 7. Effects of the NPP construction on GDP under the four main impact mechanisms (change relative to the Baseline case).

An important question for policy makers and planners is how the construction of the NPP will affect the total production output value. Only a few of the 35 sectors in the national IOT are directly affected by the NPPs construction activities namely construction, basic metals, financial services, other business activities, chemicals and electric equipment. The sector most affected by the nuclear plant construction is machinery, i.e. the manufacturing sector. The reason is that the output of the manufacturing sector is used by various other sectors such as construction, mechanical and electrical equipment. The changes triggered in the total output by the NPP construction under the four main impact mechanisms are presented in Figure 8. The impacts on total output are very similar in the cases of labour market feedback (Module ABC) and when effects of financing are also included (Module ABCD).

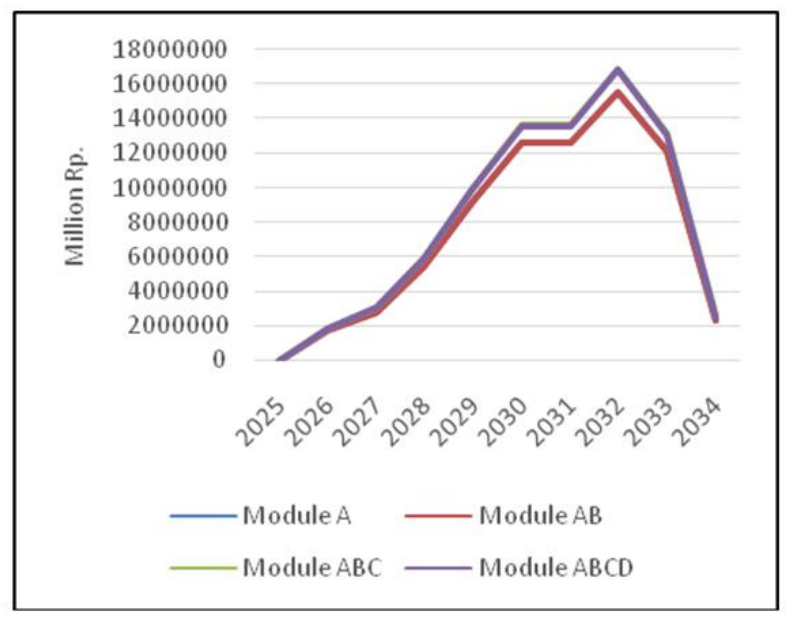

Figure. 8. Effects of the NPP construction on the total production output value under the four main impact mechanisms (change relative to the Baseline case).

\subsection{Impact on Employment}

Impacts of the NPP construction on employment is another issue of key interest to politicians and decision makers. The plant construction in Indonesia is estimated to create 66,083 jobs as direct and indirect impacts, 107,693 jobs when the repercussions of direct and indirect impacts of increasing personal incomes through employment creation by the construction (induced impacts) are also included, 86,081 jobs when labour market feedbacks on the 
rest of the economy are also counted, and 85,449 when impacts of the ex-ante financing of the plant construction from increasing the households' tax rate and/or from decreasing public transfers to households in a revenue-neutral manner during the construction phase are also considered in the assessment. The last two numbers show that the difference between the results of labour market impacts (calculated by Module $\mathrm{ABC}$ ) and the results of the financing impacts are very close. Results in relative terms compared to the Baseline case are presented in Table 3.

Table 3. Impact on Employment

\begin{tabular}{rrrrr}
\multicolumn{5}{c}{ Table 3. Impact on Employment } \\
\hline & $\begin{array}{c}\text { Module } \\
\text { A }\end{array}$ & $\begin{array}{c}\text { Module } \\
\text { AB }\end{array}$ & $\begin{array}{c}\text { Module } \\
\text { ABC }\end{array}$ & $\begin{array}{c}\text { Module } \\
\text { ABCD }\end{array}$ \\
\hline 2025 & 0 & 0 & 0 & 0 \\
2026 & 2,234 & 3,488 & 2,789 & 2,773 \\
2027 & 3,427 & 5,348 & 4,277 & 4,252 \\
2028 & 5,809 & 9,321 & 7,452 & 7,394 \\
2029 & 8,755 & 14,370 & 11,488 & 11,378 \\
2030 & 11,378 & 18,621 & 14,884 & 14,742 \\
2031 & 10,813 & 17,678 & 14,130 & 13,993 \\
2032 & 12,624 & 20,726 & 16,564 & 16,564 \\
2033 & 9,352 & 15,338 & 12,256 & 12,139 \\
2034 & 1,689 & 2,803 & 2,240 & 2,213 \\
\hline Total & 66,083 & 107,693 & 86,081 & 85,449
\end{tabular}

As the scope of impact calculations is gradually broadened from assessing only the direct and indirect impacts of the NPP construction (in Module A) to include more impact and feedback mechanisms such as induced impacts resulting from increasing personal incomes due to employment creation by the construction work and the ensuing higher household expenditures (in Module AB) and further to consider additional adjustments in response to changes in the labour market (in Module $\mathrm{ABC}$ ), all the way to incorporate the impacts of ex ante financing of the related investment costs (in Module $\mathrm{ABCD}$ ), results always include impacts calculated in the previous steps.

This pattern can also be observed when comparing the results for particular impact indicators across the extending scope of impact mechanisms. For most indicators, the calculated impacts become higher as more response mechanisms are included. The only exception is disposable income that declines slightly when effects of financing the nuclear plant investments running through the national economy (due to the funds diverted to cover the construction costs) are also included in the scope of the macroeconomic impact analysis. The difference between the results of labour market impacts (calculated by Module $\mathrm{ABC}$ ) and the results of the financing impacts (calculated by Module ABCD) are very close for the other indicators.

\section{CONCLUSION}

According to the assessments provided by the EMPOWER, the construction of a NPP has positive impacts on the national economy. All aggregated indicators (GDP, disposable income, production output value, exports, imports, private consumption and employment) increase, except net taxes for the government that show some decline during the construction period. The impacts are proportional with the amount of money spent on construction activities and with the contribution of the domestic industries in a given year.

The results of the analysis showed that NPP construction has a significant impact on GDP and employment absorption. Each of module (A, AB, $\mathrm{ABC}$ and $\mathrm{ABCD}$ ) had an impact of GDP increase of $0.021 \%, 0.033 \%, 0.040 \%$ and $0.040 \%$ respectively whencompared to the GDP gained without any NPP construction. As for the amount of employment creation in module $\mathrm{A}, \mathrm{AB}, \mathrm{ABC}$ and $\mathrm{ABCD}$ respectively equal to $66,083,107,693,86,081$ and 85,449 jobs.

Accordingly, the assessed impacts are increasing as the scope is extended, i.e. moving from Module A to ABCD.

\section{ACKNOWLEDGEMENT}

The work presented in this paper under the IAEACRP program on "Assessing The National and Regional Economic and Social Effects of Nuclear Programmes" with contract number 18669, which was managed by the Center for Nuclear Energy Assessment of National 
Nuclear Energy Agency of Indonesia (BATAN). The author would like to thank IAEA for the opportunity to join this CRP program.

\section{REFERENCES}

1. Ministry Of Energy And Mineral Resources, Presidential Regulation No. 22 year 2017 on National Energy Planning, Jakarta, 2017, [Online]. Available at: https://www.esdm.go.id/assets/media/content/conte nt-rencana-umum-energi-nasional-ruen.pdf.

2. Ministry Of Energy And Mineral Resources, Goverment Regulation No.79 year 2014 on National Energy Policy, Jakarta, 2017, [Online]. Available at: https://jdih.esdm.go.id/index.php/web/result/186/det ail.

3. Mubyarto, "Teori Investasi dan Pertumbuhan Ekonomi Dalam Ekonomi Pancasila", Jurnal Ekonomi dan Bisnis Indonesia, Vol.18, No.3, 2003.

4. Novita, Desi. "Dampak Investasi Sektor Pertanian terhadap Perekonomian Sumatera Utara (Pendekatan Analisis Input-Output)". Tesis. Sekolah Pasca Sarjana Universitas Sumatera, 2009.

5. Syamsul Hadi, et.al. Strategi Pembangunan Indonesia Pasca IMF. Granit, Jakarta, 2004.

6. National Participation, Feasibility Study of the First Nuclear Power Plants at Muria Peninsula Region, BATAN-NEWJEC CO. LTD., Jakarta, 1993.

7. Miller and Blair, Input-Output Analysis: Foundations and Extensions, Prentice-Hall, Inc, New Jersey, 1985.

8. Ratya Anindita, "Estimating The Economic Impact of Nuclear Power and Desalination Plant Construction in Indonesia", in International Conference on Policy Modeling - EcoMod2007 Proceeding, the University of Sao Paulo on July 11-13, 2007.

9. Seung-HoonYoo and Tae-HoYoo, "The role of the nuclear power generation in the Korean national economy: An input-output analysis", Progress in Nuclear Energy, Volume 51, Issue 1, January 2009

10. Manki Lee, et.al, "Contribution of Nuclear Power to The National Economic Development in Korea", Nuclear Engineering and Technology, Vol.41 No.4 May 2009.

11. Mochamad Nasrullah, Suparman, "Analisis Dampak Ekonomi Pembangunan PLTN di Indonesia Dengan Menggunakan Model Input Output", in Prosiding Seminar Nasional ReTII ke-10, Yogyakarta, 2015.

12. "Nuclear Technology and Economic Development in the Republic of Korea”, IAEA, Vienna, August 2009.

13. Kerangka Teori dan Analisis Tabel Input-Output Indonesia. Badan Pusat Statistik. Jakarta, 2000.

14. "An Extended Input-Output Model for Impact Assessment of Nuclear Power Plants (EIO-IANP)", IAEA, Vienna, December, 2015.

15. Tomislav Gelo, "Extended Input Output Model for Nuclear Power Plant Impact Assessment”, in Proceedings of The 32nd International Academic Conference, Geneva, 2017.

16. Kurt Kratena, "An Extended Input-Output Model for Impact Assessment of Nuclear Power Plants (EMPOWER II)", IAEA, Vienna, December 2019.

17. Plich, Mariusz, and Lukasz Konopielko. "Modeling
Economic Impact of Nuclear Power Plant For Poland Economic and Social Development," in Proceedings 36th International Scientific Conference on Economic and Social Development. 2018.

18. WORLD INPUT-OUTPUT DATABASE, Tables Release 2013, [Online]. Available at http://www.wiod.org/database/niots 13 .

19. "Tabel Input-Output Indonesia 2005”, Badan Pusat Statistik. Volume Pertama. Jakarta, 2005.

20. "Quarterly GDP at Current Market Prices by Industrial Origin (Billion Rupiah), 2010-2013”, BPS, 2016, [Online]. Available at https://www.bps.go.id/dynamictable/2016/02/09/113 7/-seri-2010-distribusi-pdb-triwulanan-atasdasar-harga-berlaku-menurut-lapangan-usahapersen-2010-2013.html.

21. Nuryanti et.al, "Impact Assessment of NPP Construction in Bangka Island on National Economy, CRP Final Report”. Center for Nuclear Energy System- BATAN, Jakarta, 2017.

22. "Feasibility Study For Bangka Nuclear Power Plant Project - Non Site Aspect”. PLN-JAPC, Jakarta, 2013.

23. "AP-600 National Participation Program for Indonesia”. BATAN-WESTINGHOUSE, Jakarta, 1996.

24. "ABWR Local Participation Plan for Indonesia", BATAN-GE, Jakarta, 1997.

25. "Joint Study on the Construction of KSN-1000 in Indonesia”. BATAN-KEPCO, 1998.

26. "Impact of NPP Development and Construction in Muria Peninsula on National Economy Sectors". BATAN-UGM, Jakarta, 2004.

27. "Report on the Joint Study for Program Preparation \& Planning of the NPP Development in Indonesia (Phase 2)”. BATAN-KHNP, Jakarta, 2006. 